\title{
Keterbukaan Diri dalam Komunikasi Orangtua-Anak pada Remaja Pola Asuh Orangtua Authoritarian
}

\author{
Maulana Rezi Ramadhana* \\ Universitas Telkom \\ Email: rezimaulana@telkomuniversity.ac.id* \\ *corresponding author
}

Keywords:

Self-disclosure

Authoritarian Parents Parenting

Parent-Child Communication.

\section{Kata Kunci:}

Keterbukaan Diri

Pola Asuh Orangtua Authoritarian

Komunikasi Orangtua-Anak

\begin{abstract}
Adolescents are ages in the process of growing emotional functions and psychosocial functions that are very important in the process of adjustment. This process involves self-disclosure, communicating and fostering social relations. On the other hand, teenagers who are still unstable still need care from their parents and one form of parenting applied is authoritarian. This study aims to get an overview and analysis of aspects of self-disclosure in parentchild communication in adolescents parenting authoritarian parents. The study used a mixed method descriptive method with quantitative and qualitative data through questionnaires and interviews for 2 months. Respondents in this study were 71 teenagers of new high school students in the city of Bandung who had a parenting style of authoritarian parents. The results of processing the reliability of the measuring instrument questionnaire reliability were .745 (alpha cronbach's) with strong inter-dimensional relationship analysis. The results of this study illustrate that adolescents with authoritarian parenting show self-disclosure in the medium category with the frequency dimension of interaction that is not intensive, there are positive and negative responses in conversation, candor has not appeared, self-disclosure that is not directed at the goal and the existence of a less intimate attitude in the relationship parentchild communication.
\end{abstract}

\begin{abstract}
ABSTRAK
Remaja adalah usia dalam proses pertumbuhan fungsi emosi dan fungsi psikososial yang sangat penting dalam proses penyesuaian diri. Proses ini melibatkan keterbukaan diri, berkomunikasi dan saling membina hubungan sosial. Di sisi lain, usia remaja yang masih belum stabil masih memerlukan pengasuhan dari kedua orangtuanya dan salah satu bentuk pola asuh yang diterapkan adalah authoritarian. Penelitian ini bertujuan untuk mendapatkan gambaran dan analisis aspek keterbukaan diri dalam komunikasi orangtuaanak pada remaja pola asuh orangtua authoritarian. Penelitian menggunakan metode deskriptif mixed method dengan data kuantitatif dan kualitatif melalui metode kuesioner dan wawancara selama 2 bulan. Responden dalam penelitian ini adalah 71 remaja siswa baru SMA Negeri di Kota Bandung yang memiliki pola asuh orangtua authoritarian. Hasil pengolahan data uji reliabilitas kuesioner alat ukur sebesar .745 (alpha cronbach's) dengan analisis hubungan antar dimensi yang kuat. Hasil penelitian ini menggambarkan bahwa remaja dengan pola asuh authoritarian menunjukan keterbukaan diri dalam kategori sedang dengan dimensi frekuensi interaksi yang tidak intensif, terdapat respon positif dan negatif dalam percakapan, belum muncul keterusterangan, pengungkapan diri yang tidak terarah pada tujuan dan adanya sikap kurang intim dalam hubungan komunikasi antara orangtua-anak.
\end{abstract}

Copyright (C) 2018 Channel Jurnal Komunikasi. All right reserved. 


\section{PENDAHULUAN}

Usia remaja adalah usia transisi dalam rentang kehidupan manusia, adalah usia yang terletak diantara kanakkanak dan dewasa (Santrock, 2003). Karena usia remaja adalah usia peralihan, maka banyak terjadi perubahan besar yang penting terkait dengan kematangan fungsi fisik, yang ditandai dengan perubahan hormon untuk reproduksi, perubahan hormon inilah yang selanjutnya mempengaruhi fungsi emosi pada remaja. Fungsi lainnya adalah fungsi kognitif yang ditandai dengan kemampuannya berpikirnya dalam menyelesaikan masalah secara logis, dan fungsi psikososial yang ditandai dengan mulai mendekatnya remaja pada kelompok-kelompok kawan sebaya, mengembangkan minat sosial dan menunjukkan penampilannya di lingkungan sebayanya. Dengan fungsi-fungsi tersebut, remaja mulai mengembangkan rasa ingin tahunya dan menyelaraskan tindakannya sesuai dengan minat untuk menunjukkan diri di lingkungan sosial, salah satunya dengan aktif berinteraksi dengan orang lain, baik di dalam keluarga dan lingkungan sosial secara luas.

Dihadapkan dengan situasi sosial ini, maka sangatlah penting sebuah proses penyesuaian diri bagi remaja, sehingga mereka dapat membuka diri, berkomunikasi dengan orang lain, menumbuhkan rasa percaya diri dan dapat membina hubungan harmonis di lingkungan sosialnya, konsep inilah yang disebut dengan keterbukaan diri (Buhrmester, 1995). Tanpa melibatkan keterbukaan diri, maka seorang remaja dapat menerima respon sosial yang kurang baik yang akan mempengaruhi perkembangan fungsinya identitas dirinya. Keterbukaan diri juga dinilai sangat penting dalam penentuan keberhasilan dalam melakukan interaksi sosial, baik di dalam keluarga maupun di lingkungan sebayanya, mereka akan mulai tertarik kepada orang lain dengan membuka diri dan menumbuhkan sikap saling percaya kepada orang lain (Taylor \& Belgrave, 1986). Keterbukaan diri sangatlah diperlukan bagi usia remaja karena di usia inilah mereka mulai menunjukkan kemampuannya untuk dapat menerima orang lain dan menyesuaikan diri, khususnya pada usia remaja menengah yang baru menginjak jenjang studi di Sekolah Menengah Atas.

Remaja juga dihadapkan dengan pilihan respon sosial dimana mereka mulai menunjukan sikap berkaitdan dengan pengambilan keputusan, dalam hal inilah merupakan situasi yang cukup rawan mengingat fungsi emosi remaja yang masih belum stabil, dengan demikian pengasuhan dari keluarga masih sangat diperlukan khususnya orangtua. Kohn (dalam Monk, Knoers dan Haditono, 1994) menyampaikan bahwa pola asuh merupakan peran dan sikap orang tua dalam berinteraksi dengan anak-anaknya sementara menurut BKKBN, peran orangtua bagi anaknya meliputi peran dalam memberikan bimbingan dan arahan, peran memberikan dorongan untuk menanamkan rasa percaya diri, peran mengawasi sikap dan perilaku remaja, peran mendampingi remaja ketika masa sulit dalam mengambil keputusan, peran menciptakan suasana dan komunikasi dengan baik (komunikator). Terkait dengan peran komunikator yang dimaksud meliputi cara orangtua menyampaikan pesan, menyampaikan aturan-aturan, hadiah, hukuman, cara orangtua memberikan perhatian serta merespon komunikasi anaknya.

Dalam prakteknya, setiap anak menerima gaya komunikasi orangtua yang berbeda-beda tergantung dari gaya pola asuh yang orangtua terapkan, salah satunya adalah gaya pola asuh orangtua authoritarian. Menurut Baumrind (1991) pola pengasuhan authoritarian ini ditandai dengan sikap pengawasan orangtua yang kuat dan fokus pada pendapat orangtua, sehingga ada batasan komunikasi yang tegas dalam menjalankan peran komunikasi terhadap anak-anaknya. Studi empiris yang dilakukan oleh Fagan (dalam Badingah, 1993) memaparkan bahwa orangtua yang menerapkan komunikasi dengan pola asuh authoritarian cenderung akan menghasilkan remaja yang bermasalah yang mempengaruhi kualitas karakter anak dan perilaku anak yang cenderung kurang terbuka meski disisi lain pola asuh ini juga dapat meningkatkan kemandirian. Pada dasarnya, komunikasi orangtua kepada anaknya ataupun sebaliknya dengan penerapan gaya pola asuh authoritarian ini dilakukan untuk memenuhi beberapa tujuan dari komunikasi itu sendiri, yaitu merubah sikap, merubah pendapat, merubah perilaku (Effendy, 2003), mengingat komunikasi orangtua kepada anaknya adalah aktivitas intensif tatap muka di keluarga dan keterbukaan anak berkaitan dengan bagaimana cara komunikasi yang orangtua lakukan sesuai dengan pola asuh yang diterapkan. Tujuan penelitian ini dimaksudkan untuk mendapatkan gambaran keterbukaan diri dan menganalisis aspek keterbukaan diri remaja dalam komunikasi orangtua-anak pada remaja pola asuh orangtua authoritarian di Sekolah Menengah Atas Negeri kota Bandung.

\section{TINJAUAN PUSTAKA}

\section{a. Pengertian Keterbukaan Diri (Self-Disclosure)}

Menurut Devito (1992) keterbukaan diri adalah kemampuan dalam memberikan informasi tentang dirinya kepada orang lain, informasi ini dapat terkait dengan sikap, perilaku, perasaan, keinginan, motivasi dan pendapat yang terdapat di dalam diri seseorang. Terdapat 5 (lima) dimensi keterbukaan diri yang dikemukakan yaitu :

1. Ukuran, yaitu ukuran keterbukaan diri didapat dari frekuensi seseorang menunjukan sikap terbuka dan durasi pesan-pesan komunikasi yang diperlukan untuk menyatakan pengungkapan tersebut,

2. Valensi, yaitu kualitas positif dan negatif dari pengungkapan diri,

3. Kecermatan dan kejujuran, yaitu kecermatan pengungkapan diri yang dilakukan, jika individu mengenal dirinya dengan baik maka ia akan mampu melakukan pengungkapan diri dengan cermat, lalu diarahkan pada komunikasi antarpribadi,

4. Maksud dan tujuan, individu akan menyingkapkan apa yang ditujukan untuk diungkapkan, 
5. Keintiman, individu menyingkapkan hal-hal yang intim yang bersifat pribadi.

\section{b. Pengertian Komunikasi Pola Asuh Orangtua Authoritarian}

Komunikasi pola asuh authoritarian populer dikenal dengan sebutan otoriter. Tipe komunikasi pola asuh ini cenderung kuat dalam peran orangtua sebagai pengawas terhadap anak-anaknya, sulit menerima pendapat dan cenderung memaksakan anak-anaknya untuk patuh terhadap aturan-aturan yang ditetapkan orangtuanya (Baumrind, 1991). Komunikasi orangtua pada pola asuh authoritarian ini melibatkan unsur :

1. Kontrol, artinya gaya orangtua menyampaikan pesan dengan batasan-batasan bagi anaknya secara berlebihan.

2. Kasih sayang, artinya gaya orangtua menyampaikan pesan yang seringkali tidak selalu mengikuti perasaan anaknya,

3. Komunikasi, artinya gaya orangtua menyampaikan pesan dengan tidak memberikan waktu pada anaknya untuk berpendapat,

4. Tuntutan kedewasaan, artinya gaya orangtua menyampaikan pesan yang menuntut tingkat kemampuan intelektual dan emosional tanpa diberikan kesempatan pada anak untuk kompromi.

\section{METODE PENELITIAN}

Penelitian ini menggunakan metode deskriptif mixed methods (kuantitatif dan kualitatif). Pada penelitian ini peneliti berusaha untuk memaparkan dan memberikan penafsiran data yang ada untuk mendapatkan gambaran secara sistematis tentang keterbukaan diri dalam komunikasi orangtua-anak pada remaja pola asuh authoritarian. Menurut Hidayat (dalam Azwar, 2009), metode penelitian deskriptif adalah metode penelitian yang digunakan untuk menemukan pengetahuan yang luas terhadap sebuah objek penelitian pada masa tertentu. Sifat penelitian ini adalah expost facto, dimana penelitian dilakukan untuk meneliti peristiwa yang telah terjadi. Populasi dalam penelitian ini sejumlah 71 orang remaja siswa didik baru Sekolah Menengah Atas Negeri di kota Bandung yang memiliki karakteristik tinggal bersama kedua orangtuanya dan disaring berdasarkan kategori remaja pola asuh authoritarian. (melalui survei dan penelitian sebelumnya oleh pihak sekolah setempat). Penelitian ini dilaksanakan selama 2 bulan, dimulai pada bulan Juli hingga Agustus tahun 2018.

Metode pengumpulan data pada penelitian ini menggunakan skala bentuk kuesioner tertutup dan wawancara. Kuesioner skala instrumen keterbukaan diri terdiri dari 60 butir aitem dengan menggunakan respon 4 skala (4=Sangat Sesuai, $3=$ Sesuai, $2=$ Tidak Sesuai, $1=$ Sangat Tidak Sesuai). Uji validitas pengukuran dalam penelitian ini menggunakan corrected item totally correlation dengan cara mengkorelasikan setiap skor butir item dengan skor total, kemudian dilakukan korelasi terhadap nilai koefisien korelasi yang teroverestimasi. Menurut Azwar (2009), kriteria dapat dikatakan sahih/valid jika koefisien sama dengan atau melebihi 0,30 dimana daya pembedanya telah dianggap memuaskan, sementara dikatakan tidak sahih/tidak valid jika kurang dari 0,30 dimana dapat diinterpretasikan sebagai butir aitem yang memiliki daya pembeda yang rendah. Sementara teknik analisis data untuk mendapatkan nilai variabel pengukuran adalah dengan membandingkan skor rata-rata dengan kategorisasi pada kurva normal ideal. Didapatkan skor minimum $\left(\mathrm{X}_{\min }\right)$ dan skor maksimum $\left(X_{\text {max }}\right)$ dan mencari skor rata-rata (mean) ideal $\left(M_{i}\right)$ dengan menggunakan rumus $M_{i}=1 / 2\left(X_{\max }+\right.$ $\left.\mathrm{X}_{\min }\right)$ dan standar deviasi ideal $\left(\mathrm{S}_{\mathrm{Di}}\right)$ dengan rumus $\mathrm{S}_{\mathrm{Di}}=1 / 6\left(\mathrm{X}_{\max }+\mathrm{X}_{\min }\right)$. Selanjutnya peneliti melakukan kategorisasi variabel yaitu Sangat Tinggi, Tinggi, Sedang, Rendah dan Sangat Rendah. Sementara Pengujian reliabilitas menggunakan uji alpha cronbach's, instrumen dapat dikatakan reliabel jika memiliki koefisien alpha cronbach's melebihi angka 0,600

Terkait dengan penelitian sebelumnya yang dilakukan oleh Abdollahi \& Abu Thalib (2013) ditemukan bahwa adanya korelasi positif antara komunikasi orangtua gaya pengasuhan dan keterbukaan diri $(\mathrm{r}=.479)$ dan ditemukan juga bahwa jenis kelamin (gender) memoderasi hubungan gaya pengasuhan dan pengungkapan diri remaja. Penelitian selanjutnya yang dilakukan oleh Esti Purnamasari (2016), menemukan adanya pengaruh antara pola asuh orangtua terhadap faktor keterbukaan diri siswa SMA, dalam hal ini pola asuh orang tua memberikan kontribusi sebesar $11 \%$ terhadap keterbukaan diri remaja.

\section{HASIL DAN ANALISIS}

Hasil validitas variabel skala keterbukaan diri setelah menggunakan corrected item totally correlation menunjukkan hasil 35 butir aitem valid (koefisien diatas 0,30 ) yang digunakan dari total 60 butir aitem yang dirancang. Skor maksimal pengukuran keterbukaan diri adalah 140 dan skor minimal adalah 35. Hasil responden diperoleh skor tertinggi adalah 112 dan skor terendah 75. Sementara nilai rata-rata didapatkan sebesar 95.4. Melalui teknik analisis didapatkan mean ideal $\left(\mathrm{M}_{\mathrm{i}}\right)$ sebesar 93.5 dengan perhitungan standar deviasi ideal $\left(\mathrm{S}_{\mathrm{Di}}\right)$ sebesar 6.17. Hasil uji reliabilitas untuk variabel skala keterbukaan diri ini sebesar 0.745 , variabel tersebut memiliki nilai alpha cronbach's diatas 0,600 sehingga dapat disimpulkan bahwa instrumen penelitian ini dapat layak digunakan untuk pengambilan data penelitian. 
Tabel 1. Distribusi variabel pengukuran keterbukaan diri pada remaja pola asuh orangtua authoritarian

\begin{tabular}{ccccc}
\hline Category & Range Score & Frequency & Percent & Valid Percent \\
\hline Sangat Tinggi & $>105.80$ & 11 & $6.5 \%$ & $6.5 \%$ \\
Tinggi & $99.67-105.80$ & 20 & $11.8 \%$ & $11.8 \%$ \\
Sedang & $93.50-99.66$ & 13 & $7.6 \%$ & $7.6 \%$ \\
Rendah & $87.33-93.49$ & 11 & $6.5 \%$ & $6.5 \%$ \\
Sangat Rendah & $<87.33$ & 16 & $9.4 \%$ & $9.4 \%$ \\
\hline TOTAL & & 71 & $100 \%$ & $100 \%$ \\
\hline
\end{tabular}

Sumber : Data yang diolah, 2018

Dari tabel 1 diatas menunjukan distribusi variabel pengukuran keterbukaan diri pada remaja pola asuh orangtua authoritarian, didapatkan hasil paling banyak pada kategori tinggi (11.8\%), sementara skor rata-rata ( $\dot{\mathrm{x}}) 95.4$ termasuk kategori sedang (93.50- 99.66). Berdasarkan olahan data diatas menunjukkan bahwa keterbukaan diri remaja pola asuh orangtua authoritarian pada siswa didik baru Sekolah Menengah Atas Negeri di kota Bandung tergolong sedang.

Poin penting bagi remaja dengan pola asuh orangtua authoritarian adalah adanya aturan ketat yang diterapkan oleh orangtua. Aturan yang diterapkan biasanya sepihak dan para orangtua cenderung tidak membuka kesempatan bagi anaknya untuk berdiskusi. Hal ini tentu dapat mempengaruhi kuantitasnya dalam melakukan komunikasi, ini mempengaruhi keintiman anak dengan orangtuanya. Selain aturan, orangtua dengan gaya authoritatian punkerap memberikan batasan perilaku dan pemberlakuan hukuman, mulai dari amarah hingga pembatasan-pembatasan keinginan anaknya, yang selanjutnya situasi ini dapat memberikan jarak intim bersama anaknya. Komunikasi pola asuh authoritarian lebih diwarnai oleh tataran logis, kurang menyentuh sisi perasaan anak sehingga turut mempengaruhi pola komunikasi yang kurang interaktif di dalam keluarga. Kurangnya keinginan untuk saling membuka diri anak bersama orangtua, membuat anak akan lebih memilih nyaman berdiam diri dan berperilaku menurut, terlebih karena pada usia remaja awal ini mereka belum memiliki reaksi emosi yang cukup matang. Keterbukaan diri remaja terkategorikan sedang juga dapat disebabkan oleh kurangnya orangtua memberikan apresiasi terhadap apa yang telah anak lakukan atau perjuangan, disamping juga perhatian yang terbatas kepada anaknya memberikan efek diadik yang sama oleh anak terhadap orangtuanya, terdapat 48 orang $(68 \%)$ responden remaja cenderung juga tidak merasa peduli terhadap situasi yang dialami orangtuanya. Sementara 37 orang $(52 \%)$ responden remaja lebih memilih untuk tidak berlama-lama melakukan komunikasi dengan orangtuanya karena menghindari sesuatu hal (respon) yang kurang mengenakkan bagi anaknya. Bagi remaja pola asuh orangtua authoritarian komunikasi orangtua-anak dilakukan sebatas fungsional, untuk menghindari umpan balik komunikasi.

Sebanyak 41 orang (58\%) responden remaja mengaku tidak merasa dilibatkan untuk berdiskusi karena semuanya sudah ditentukan oleh kedua orangtuanya, contohnya tentang pilihan sekolahnya di SMA, pilihan tentang tempat les, dll, Kalaupun terjadi komunikasi yang meneguhkan pilihan anaknya, maka maka tetap akan terkena umpan balik negatif, contohnya anak diminta tanggung jawab sendiri, menyampaikan kalimat "terserah kamu, mama sudah cari-cari cara", “jangan salahin mama kalau kamu nanti gagal”, dll. Kurangnya anak diberikan kesempatan berpendapat, mempengaruhi anak menjadi tidak percaya diri. Dari informasi tersebut tampak orangtua memiliki peran utama yang dominan dalam pengambilan keputusan, orangtua menginginkan semua pendapatnya diikuti. Bentuk komunikasi orangtua kepada anaknya untuk pola asuh authoritarian cenderung persuasif. Hasil survei dari seluruh responden (100\%) remaja dengan pola asuh orangtua authoritarian terkait dengan pernyataan dan kalimat yang paling sering kali diucapkan oleh orangtua saat berkomunikasi, sebagai berikut :

Tabel 2 . Kalimat yang sering diucapkan orangtua pola asuh authoritarian dan distribusi sebaran responden remaja $(\mathrm{n}=71)$

\begin{tabular}{ll}
\hline \multicolumn{1}{c}{ Pernyataan } & Sebaran \\
\hline "mama/papa kan udah bilang...., mama/papa udah kasitau ya...” & 61 responden \\
"kamu kok ngga nurut sih...., kamu ko ga mau denger omongin mama...” & 43 responden \\
"terserah kamu, pokoknya mama/papa udah ngingetin..." & 35 responden \\
"ko gini aja kamu ga bisa,..., kamu mau jadi apa kalau gini"” & 33 responden \\
"nih....mama/papa udah bayar/pilih, kamu harus nurut" & 31 responden \\
"mulai besok, ga ada main keluar..., udah, diam dirumah, belajar." & 23 responden \\
"hebat dia ya, dia lebih bagus dari kamu lho." & 18 responden \\
\hline
\end{tabular}

Sumber: Data yang diolah, 2018

Berdasarkan jenis kelamin, menunjukkan bahwa remaja pola asuh orangtua authoritarian perempuan $(\dot{\mathrm{x}}=99.2)$ lebih menunjukan keterbukaan diri dibandingkan remaja pola asuh orangtua authoritarian laki-laki. ( $\dot{\mathrm{x}}=90.1)$. Umumnya remaja pola asuh orangtua authoritarian sulit untuk dapat berkomunikasi dengan orangtuanya, mayoritas responden mensikapi jika berbicara seringkali selalu salah, jika meminta sesuatu yang diinginkan seringkalu sulit terwujud karena banyak perjanjian dan tuntutan, seperti nilai akademis yang harus tinggi, dll. sebanyak 34 orang (83\%) responden 
remaja perempuan merasa jenuh dengan aturan-aturan yang orangtua terapkan dan merasa tidak bebas, pilihannya hanya dua, yaitu menuruti atau dimarahi. Bahkan beberapa remaja perempuan merasakan ketakutan hingga malas bertemu (bahkan) melihat wajah orangtuanya. Mengatasi hal tersebut, beberapa remaja perempuan masih mampu mengeluarkan keterbukaan ekspresinya dengan cara menulis, bernanyi, nonton youtube sampai curhat sesama kawan. Sementara remaja laki-laki umumnya (90\%) lebih banyak menggunakan waktunya diluar rumah (perilaku malas dirumah), kalaupun di dalam rumah ia lebih memilih untuk berdiam di kamar, main game online atau tidur. Dari data tersebut dapat ditafsirkan jika remaja perempuan lebih bisa mengekpresikan dirinya dibanding remaja laki-laki. Baik remaja perempuan maupun laki-laki, umumnya mereka mulai dapat berkomunikasi dengan orangtua mereka saat orangtua mulai menanyakan dan membahas hobi atau kesukaan mereka atau saat orangtua meminta bantuan (efek diadik). Menurut Pearson (1980) jenis kelamin menyebabkan perbedaan keterbukaan diri, sementara Cunningham (1981) dalam studinya memaparkan bahwa perempuan lebih sering untuk terbuka para perasaan, memberikan perhatian kekurangan atau kelebihan diri, perempuan juga lebih emosional dibandingkan laki-laki yang lebih menahan diri.

Remaja pola asuh orangtua authoritarian lebih dapat berkomunikasi dengan ibunya(45.1\%) ketimbang ayahnya (14.1\%). Ibu adalah figur signifikan yang melahirkan dan merawat anak-anaknya. Ibu juga bisa menjadi benteng bagi keluarganya yang dapat menguatkan setiap anggota keluarganya (Santoso, 2009). Meski dirasakan oleh sebagian besar remaja pola asuh orangtua authoritarian bahwa ibu seringkali banyak mengatur, namun remaja tetap mensikapi sosok ibulah yang paling mudah dijumpai karena lebih intensif bertatap muka di rumah, sementara sosok ayah dianggap lebih jarang berkomunikasi tatap muka. Komunikasi yang dilakukan dengan ayah umumnya sebatas saling menanyakan kabar, tidak jarang juga anak menerima suruhan atau permintaan ayahnya untuk melakukan sesuatu hal. Berbeda komunikasi dengan ibu yang dirasakan lebih sering berbicara membahas rutinitas yang telah dikerjakan, seperti situasi di sekolah, menanyakan tugas-tugas sampai membahas orang lain yang pada akhirnya mengarah pada kecederungan membandingbandingkan anaknya dengan orang lain. 39 orang (55\%) remaja pola asuh orangtua authoritarian merasakan sering dibanding-bandingkan dengan teman-temannya oleh Ibu maupun Ayah, topiknya selalu mengarah pada nilai akademik, gaya berpenampilan (perempuan), mereka mensikapinya dengan jengkel yang ditandai dengan perasaan tidak nyaman, mereka pun sering merasa down dan menjadi tidak percaya diri. Menurut peneliti, perilaku membanding-bandingkan anaknya dengan kawan usia sebayanya dapat mempengaruhi rasa percaya diri. Alih-alih dengan tujuan memotivasi anaknya, namun tidak semua anak remaja mampu menerima dan menyerap makna di balik perkataan yang orangtuanya maksudkan, ini karena fungsi emosi yang baru muncul dan masih belum stabil, bagi seorang remaja pengaruh situasional cukup mewarnai keterlibatan perasaannya.

Remaja pola asuh orangtua authoritarian umumnya kurang keterbukaan diri karena memiliki Ayah yang bekerja dan Ibu yang bekerja pula (43.7\%). Dengan situasi ayah dan ibu yang bekerja, maka perhatian dan pengawasan biasanya dilimpahkan pada kerabat atau sanak saudaranya. Namun demikian, pola pengasuhan anak tetap berjalan dan bergantung pada aturan. Aturan seyogyanya dapat dipahami oleh orangtua dan anak untuk mengontrol dan mencegah terjadinya perilakunya yang tidak diharapkan, hanya saja kurangnya pembekalan informasi terhadap aturan dapat memberikan dampak menjadi kurang adaptifnya perilaku anak terhadap aturan tersebut. Survei dari 45 remaja (63\%) pola asuh authoritarian tentang aturan-aturan rutinitas yang diterapkan mendapati hasil sebagai berikut :

Tabel 3. Daftar aturan-aturan yang sering diingatkan oleh orangtua pola asuh authoritarian dan distribusi sebaran responden remaja $(\mathrm{n}=45)$

\begin{tabular}{ll}
\hline \multicolumn{1}{c}{ Pernyataan } & Sebaran \\
\hline Aturan tentang berpergian dengan kawan / bergaul & 32 responden \\
Aturan tentang pilihan makanan / aturan makan & 26 responden \\
Aturan tentang jam pulang sekolah / dan waktu belajar & 24 responden \\
Aturan tentang pembelian barang / konsumsi / berbusana & 22 responden \\
Aturan tentang menempati aturan / etika & 18 responden \\
\hline
\end{tabular}

Sumber : Data yang diolah, 2018

Selain itu dengan kondisi Ayah yang bekerja dan ibu yang bekerja juga komunikasi yang hadir seringkali tidak dapat berjalan secara diadik (percakapan tatap muka) karena kesibukan dan fokus tuntutan profesi dan pekerjaan. Sejauh ini komunikasi dengan orangtua tetap berjalan hanya dengan menggunakan sosial media. Tampak pada remaja pola asuh orangtua authoritarian percakapan diadik diantara orangtua-anak dilakukan dengan waktu yang terbatas. 
Tabel 4. Kisaran rata-rata rutinitas durasi tatap muka dan durasi percakapan remaja pola asuh orangtua authoritarian bersama ayah dan Ibu perhari $(n=71)$

\begin{tabular}{lll|ll}
\hline \multirow{2}{*}{ Remaja } & \multicolumn{2}{c|}{ Ayah } & Ibu \\
\cline { 2 - 5 } & $\begin{array}{c}\text { Tatapmuka/ } \\
\text { hari }\end{array}$ & $\begin{array}{c}\text { Durasi Percakapan/ } \\
\text { hari }\end{array}$ & $\begin{array}{c}\text { Tatapmuka/ } \\
\text { hari }\end{array}$ & $\begin{array}{c}\text { Durasi Percakapan/ } \\
\text { hari }\end{array}$ \\
\hline Laki-laki & \pm 300 menit & \pm 15 menit & \pm 350 menit & \pm 18 menit \\
Perempuan & \pm 325 menit & \pm 12 menit & \pm 420 menit & \pm 24 menit \\
\hline
\end{tabular}

Sumber: Data yang diolah, 2018

Terkait dengan dimensi keterbukaan diri, didapati hasil pengolahan sebagai berikut :

Tabel 5. Korelasi Pearson antar dimensi keterbukaan diri

\begin{tabular}{lc}
\hline Dimensi Keterbukaan Diri (Devito, 1992 & Pearson Correlation \\
\hline Ukuran & .613 \\
Valensi & .692 \\
Kecermatan dan Kejujuran & .752 \\
Maksud dan Tujuan & .714 \\
Keintiman & .434 \\
\hline
\end{tabular}

Sumber : Data yang diolah, 2018

Data pada tabel 5 diatas menunjukan pearson correlation antar aspek keterbukaan diri, koefisien korelasi digunakan dalam pengukuran kekuatan dan arah hubungan liniear antar dimensi keterbukaan diri. Dari data diatas dapat disimpulkan bahwa seluruh dimensi keterbukaan diri remaja pola asuh orangtua authoritarian menunjukkan hubungan antar aspek dimensi yang kuat, namun hubungan yang kuat tidak selalu dapat diartikan ada hubungan maupun ada sebabakibat.

Tabel 6. Distribusi skor aspek dimensi keterbukaan diri remaja pola asuh orangtua authoritarian

\begin{tabular}{lcc}
\hline Dimensi Keterbukaan Diri (Devito, 1992 & Skor Rata-Rata & Kategori \\
\hline Ukuran & 15.7 & Sedang $(15.5-17.3)$ \\
Valensi & 21.9 & Sedang $(20.5-23.0)$ \\
Kecermatan dan Kejujuran & 24.9 & Rendah $(22.6-25.0)$ \\
Maksud dan Tujuan & 19.5 & Sedang $(17.5-19.6)$ \\
Keintiman & 13.2 & Sedang $(12.5-14.3)$ \\
\hline
\end{tabular}

Sumber : Data yang diolah, 2018

Data hasil penelitian menunjukkan dimensi ukuran dalam keterbukaan diri pada remaja pola asuh orangtua authoritarian tergolong sedang. Artinya, jumlah informasi yang remaja ungkapkan dalam Komunikasi Orangtua-anak atau frekuensi remaja dalam menyampaikan pesan tidaklah lama. Dari waktu berkomunikasi dengan orangtua, hanya sedikit saja waktu yang digunakan untuk menyampaikan pesan-pesan yang mengandung makna pengungkapan diri remaja. Hal ini tampak selaras dengan data tabel 4. Untuk dimensi valensi dalam keterbukaan diri pada remaja pola asuh orangtua authoritarian tergolong sedang. Artinya, kualitas komunikasi dalam keterbukaan diri pada orangtua dapat menghasilkan respon-respon positif maupun negatif. Hal ini tampak selaras dengan data tabel 2.

Untuk dimensi kecermatan dan kejujuran dalam keterbukaan diri pada remaja pola asuh orangtua authoritarian tergolong rendah. Artinya, remaja belum mampu mengenal dengan baik dirinya, belum dapat menyatakan keterbukaan secara jujur, peneliti menduga komunikasi terjalin diantara orangtua-anak hanya dalam tataran basa-basi atau sekedar saling menyapa. Dalam berkomunikasi, remaja tidak menyampaikan pengungkapannya secara jujur mengingat ia dihadapkan dengan aturan-aturan yang membatasi mereka untuk berpendapat. Untuk dimensi maksud dan tujuan dalam keterbukaan diri pada remaja pola asuh orangtua authoritarian tergolong sedang. Artinya, pengungkapan diri selama komunikasi orangtua-anak tidak selalu terarah pada maksud dan tujuan. Hal ini seringkali berjalan secara spontan dengan tujuan yang tidak dirancang sebelumnya. Menyikapi pola asuh orangtua authoritarian, remaja umumnya tidak memiliki rencana pembicaraan yang terfokus, mengingat arah komunikasi orangtua yang cendering persuasif, menyulitkan bagi remaja untuk mengatur arah pembicaraan. Hal ini juga dikhawatirkan mereka sebagai bentuk antisipasi respon umpan baliknya yang tidak selalu positif diterima. Untuk dimensi keintiman dalam keterbukaan diri pada remaja pola asuh orangtua authoritarian tergolong sedang. Artinya, apa yang diungkapkan tidak selalu hal-hal yang bersifat pribadi, melainkan pembahasan umum yang seringkali tidak relevan dengan kondisi diri. Selain itu, penjelasan pada dimensi ini juga dapat mengungkapkan kurangnya keintiman dalam komunikasi orangtua-anak. 


\section{KESIMPULAN}

Berdasarkan uraian hasil penelitian di atas, dapat diketahui bahwa keterbukaan diri remaja pola asuh orangtua authoritarian pada siswa didik baru Sekolah Menengah Atas Negeri di kota Bandung tergolong sedang yang ditandai oleh kurangnya keinginan untuk saling membuka diri antara orangtua dan anak, artinya pola asuh orangtua authoritarian dalam penelitian ini tidak meningkatkan keterbukaan diri remaja. Pola komunikasi orangtua-anak pada pola asuh orangtua authoritarian seringkali bersifat spontan dan hanya sedikit waktu yang digunakan untuk menyampaikan pesanpesan yang mengandung makna pengungkapan diri remaja. Selain itu juga komunikasi yang terjalin sebatas normatif dan fungsional dengan bentuk komunikasi orangtua yang cenderung persuasif. Kualitas komunikasi dalam keterbukaan diri remaja pada orangtua pola asuh authoritarian dapat menghasilkan respon-respon positif maupun negatif, dan hal ini benar disikapi oleh remaja akan kekhawatirannya terhadap umpan baliknya selama proses komunikasi. Dengan demikian, remaja seringkali tidak menyampaikan pengungkapannya secara terus terang. Sementara temuan baru dalam penelitian ini adalah pola asuh orangtua authoritarian dapat mempengaruhi sikap percaya diri remaja. Sebagai hasil pelengkap dalam penelitian ini adalah ibu merupakan figur signifikan yang dinilai lebih dapat didekati daripada ayah, sementara remaja perempuan dinilai lebih mampu membuka diri daripada remaja laki-laki.

Terkait dengan peran orangtua dalam hasil penelitian ini, peneliti menduga hanya peran pengawas saja yang signifikan terungkap, sementara peran orangtua lainnya tidak terelaborasi dengan jelas. Penelitian ini menjawab permasalahan seputar tantangan keterbukaan diri dalam proses komunikasi orangtua-anak khusus bagi seorang remaja dengan pola asuh orangtua authoritarian. Namun demikian, cara untuk memulai mengungkapkan diri untuk remaja dalam pola asuh orangtua authoritarian ini adalah dapat dimulai dengan bersama-sama mendiskusikan seputar hobi dan kesukaan bersama atau melakukan pembahasan sesuatu hal yang tidak relevan dengan kondisi diri.

\section{DAFTAR PUSTAKA}

Abdollahi \& Abu Thalib. (2013). Perceived parenting styles and emotional intelligance among iranian boy students. Asian Journal of Social Sciences \& Humanities, 3 (1), 460-467.

Azwar, Saifuddin. (2009). Metode Penelitian. Pustaka Pelajar. Yogyakarta.

Badingah, S., 1993, Agresifitas Remaja Kaitannya Dengan Pola Asuh, Tingkah Laku Agresif Orang Tua, Tesis: PPS Universitas Indonesia. Jakarta.

Baumrind, D. (1991). The influence of parenting style on adolescent competence and substance use. The Journal of Early Adolescence, 11 (2), 56-95.

BKKBN. (2008). Peran orangtua dalam pembinaan remaja. Diakses 10 Agustus 2018. http://jabar.bkkbn.go.id/Lists/ Artikel.

Buhrmester, D., \& Prager, K. (1995). Patterns of self-disclosure during childhood and adolescence. In K. J. Rotenberg (Ed.), Disclosure processes in children and adolescents (pp. 10-56). Cambridge University Press. Cambridge, UK:

DeVito, Joseph A. (2007). The Interpersonal Communication Book. edisi 11. Pearson Educations.

Effendy, Onong Uchjana. (2003). Ilmu Komunikasi, Teori dan Praktek. Remaja Rosdakarya. Bandung

FJ. Kenoers Monks dan Haditono. 1994. Psikologi Perkembangan. Cetakan ke IX. Yogyakarta : Gadjah Mada University Press. Yogyakarta.

Purnamasari, Erni. (2016). Pengaruh Pola Asuh Orang Tua Terhadap Keterbukaan Diri Remaja Siswa Kelas X Smk Negeri 02 Salatiga Tahun Ajaran 2015/2016. Skripsi (diterbitkan). Universitas Kristen Satya Wacana. Salatiga.

Santrock, J.W. (2002). Life-Span Development: Perkembangan Masa Hidup (edisi kelima). (Penerj. Achmad Chusairi, Juda Damanik; Ed. Herman Sinaga, Yati Sumiharti). Erlangga. Jakarta. 
